\title{
Seasonal variation in yield, nutritive value, and antioxidant capacity of leaves of alfalfa plants grown in arid climate of Saudi Arabia
}

\author{
Walid Soufan $^{1 *}$, Mohammad K. Okla ${ }^{2}$, Ahmad Salamatullah ${ }^{1}$, Khizar Hayat ${ }^{1}$, \\ Mostafa A. Abdel-Maksoud ${ }^{2}$, and Saud S. Al-Amri ${ }^{2}$ \\ ${ }^{1}$ King Saud University, College of Food and Agriculture Sciences, P.O. Box 2460, Riyadh 11451, Saudi Arabia. \\ "Corresponding author (wsoufan@ksu.edu.sa). \\ ${ }^{2}$ King Saud University, College of Science, P.O. Box 2455, Riyadh 11451, Saudi Arabia.
}

Received: 15 November 2020; Accepted: 10 February 2021; doi:10.4067/S0718-58392021000200182

\begin{abstract}
In addition to its high nutritional value, alfalfa (Medicago sativa L.) has several health benefits including antioxidant, neuroprotective, antimicrobial, antiulcer, hypocholesterolemic, hypolipidemic, and estrogenic effects. We aimed to assess the nutritional value and antioxidant capacity of alfalfa leaves at different times of the year in arid regions. Alfalfa was harvested in autumn, winter, spring, and summer and fresh yield and leaf:stem ratio were measured. Leaves were collected to determine their nutritional value and antioxidant capacity using two different extracts viz:: absolute ethanol or distilled water. Fresh yield and leaf:stem ratio were highest in spring (20 tha $\mathrm{tan}^{-1}$ and $57.6 \%$, respectively), followed equally by winter and autumn, and were lowest in summer (10.75 tha $\mathrm{tan}^{-1}$ and $51.6 \%$, respectively). The autumn cut had the highest crude protein (33.52\%) and crude fat content (3.79\%) and the lowest content of crude fiber (13.95\%) and acid detergent fiber $(16.55 \%)$, which are good indicators of suitability for human nourishment. However, leaves collected in autumn were characterized by lower digestibility values (86.2\%) compared to the other cuts. Antioxidant capacity of leaves harvested in autumns and extracted with either ethanol or distilled water was examined in terms of total polyphenols, total flavonoids, DPPH scavenging capacity, and reducing power. Ethanol extract showed higher antioxidant capacity in terms of total phenol and total flavonoid contents (6.41 and $4.88 \mathrm{mg}$ gallic acid equivalents $\mathrm{g}^{-1} \mathrm{DW}$, respectively). These results suggest that autumn is the most appropriate season to cut alfalfa leaves for human nutritional purposes.
\end{abstract}

Key words: Antioxidants, DPPH, flavonoids, food additives, nutrition, polyphenols.

\section{INTRODUCTION}

Alfalfa (Medicago sativa L.) is a perennial herb belonging to the Fabaceae family. It is one of the most important forage crops globally and therefore, it is commonly known as the "queen of forages". Recently, alfalfa has been proposed as an important source of protein for human nourishment. Due to its high protein content, alfalfa may be an alternative, inexpensive, and sustainable protein source to mitigate the extensive use of animal protein resulting from exponential global population growth (Morin et al., 2011; Hadidi et al., 2019). It is used in nutritional supplement products, as a garnish, and in the form of tablets and/or drinks to improve digestion (Stochmal and Oleszek, 2007). The green leaves of alfalfa plants are rich sources of protein (Firdaous et al., 2017). However, they have not been fully utilized in human nourishment until now. In general, phytochemical studies on green alfalfa leaves have shown that the major active compounds found in these leaves are vitamins, flavonoids, saponins, coumarins, phytoestrogens, amino acids, alkaloids, digestive enzymes, terpenes, and phytosterols (Bora and Sharma, 2011; Silva et al., 2016; Getachew et al., 2018). Alfalfa may be used for its 
antioxidant, neuroprotective, antimicrobial, antiulcer, hypocholesterolemic, hypolipidemic, and estrogenic effects (Bora and Sharma, 2011; Al-Dosari, 2012; Bákonyi et al., 2020). Furthermore, it can potentially be used to treat heart disease, menopausal symptoms in women, cancer, diabetes, stroke, and atherosclerosis (Bora and Sharma, 2011; Rahman and Parvin, 2014; Sadeghi et al., 2016).

In animal feed, alfalfa is added to increase antioxidant activity of blood serum and liver. Such enhancement ability of alfalfa is attributed mainly to its contents of flavonoids and phenols (Eruygur et al., 2018; Chen et al., 2020). Flavonoids extracted from alfalfa leaves were reported to have high antioxidant activity in terms of diphenylpicryl hydrazine (DPPH) scavenging and ABTS assay (Jing et al., 2015). Furthermore, alfalfa-derived flavonoids enhanced the in vitro activity of different antioxidant enzymes, e.g., catalase and superoxide dismutase (Ouyang et al., 2016). Similar to flavonoids, phenols are known as strong antioxidant molecules that enhance immunity and disease resistance via inhibiting the production of reactive oxygen species that oxidize proteins, lipids, and DNA causing oxidative stress (Silva et al., 2006; Al-Rimawi et al., 2016). However, studies of the nutritional value and antioxidant activity of alfalfa leaves and the impact of seasonal changes on them are lacking. Therefore, in the current study, we aimed to assess the nutritional value of alfalfa leaves in the four different seasons of the year, to identify the most suitable season to utilize alfalfa leaves grown in arid regions for human nourishment.

\section{MATERIALS AND METHODS}

\section{Study design}

Experiments were performed at the Agricultural Research Station in Dirab, Riyadh ( $24^{\circ} 250^{\prime}$ N, $46^{\circ} 340^{\prime}$ E; 400 m a.s.l.), Saudi Arabia, during the period from 2013 to 2015. A randomized complete block design was used in this study and the plants were randomly cultivated in blocks of $4 \times 3 \mathrm{~m}$. Plant cultivation was performed with three replicates. Climate data for the study years are shown in Figure 1.

\section{Plant cultivation and sampling}

Seeds of the local alfalfa (Medicago sativa L.) 'Alhassawy' were cultivated on 10 November 2013 for 2 yr (2013-2014 and 2014-2015). Seeding rate was $40 \mathrm{~kg} \mathrm{ha}^{-1}$ in $4 \times 3 \mathrm{~m}$ plots with a spacing of $15 \mathrm{~cm}$ between lines. Irrigation and fertilization were applied following the standards of the study region. The first cut was performed after 3 -mo of cultivation and further cuts were performed regularly, at the start of the flowering stage during the growth period. The cutting height was $5 \mathrm{~cm}$ and after cutting, fresh yield $\left(\mathrm{t} \mathrm{ha}^{-1}\right)$ was estimated. Alfalfa plants were randomly sampled during each season and leaves were separated from stems and weighed to calculate the ratio of leaves to stems. A random leaf was chosen from each plot for further analysis.

\section{Nutritive value analysis}

All chemical analyses were performed in the laboratories of the College of Food and Agricultural Sciences, King Saud University and Verband Deutscher Landwirtschaftlicher Untersuchungs-und Forschungsanstalten (VDLUFA) e.V., Speyer, Germany. Dry matter content was determined by weighing fresh alfalfa leaves (W1), oven-drying the leaves at $65^{\circ} \mathrm{C}$ for $48 \mathrm{~h}$, and then weighing them again (W2). DM percentage was then calculated. The dried leaves were ground into a fine powder and used for further analysis. Crude ash (CA) content was measured by combusting a known amount of leaves for $6 \mathrm{~h}$ at $550{ }^{\circ} \mathrm{C}$. Crude protein (CP), fiber, neutral detergent fiber (NDF), acid detergent fiber (ADF), crude fat (CFA), and water-soluble carbohydrates (WSC) content were determined using a feed and forage analyzer (NIRSystems 5000, FOSS GmbH, Hamburg, Germany). Digestibility of alfalfa DM was also examined using the feed and forage analyzer as an indicator for the nutritive value at different seasons.

\section{Total polyphenol content}

Based on the nutritive values, the autumn sample was selected for further determination of total polyphenol, total flavonoid, diphenylpicryl hydrazine (DPPH) scavenging, and reduction power. For extraction, $1 \mathrm{~g}$ dried alfalfa powder was extracted with $20 \mathrm{~mL}$ of either absolute ethanol or distilled water using a shaker $(200 \mathrm{rpm})$ at $25^{\circ} \mathrm{C}$ for $1 \mathrm{~h}$. Then the mixture was centrifuged at $6000 \mathrm{rpm}$ for $10 \mathrm{~min}$ at room temperature. The supernatant was filtered using a Whatman filter paper number 2 and the obtained extract was used for further analyses. 
Figure 1. Temperature and rainfall data in the study region during the years 2013-2015.
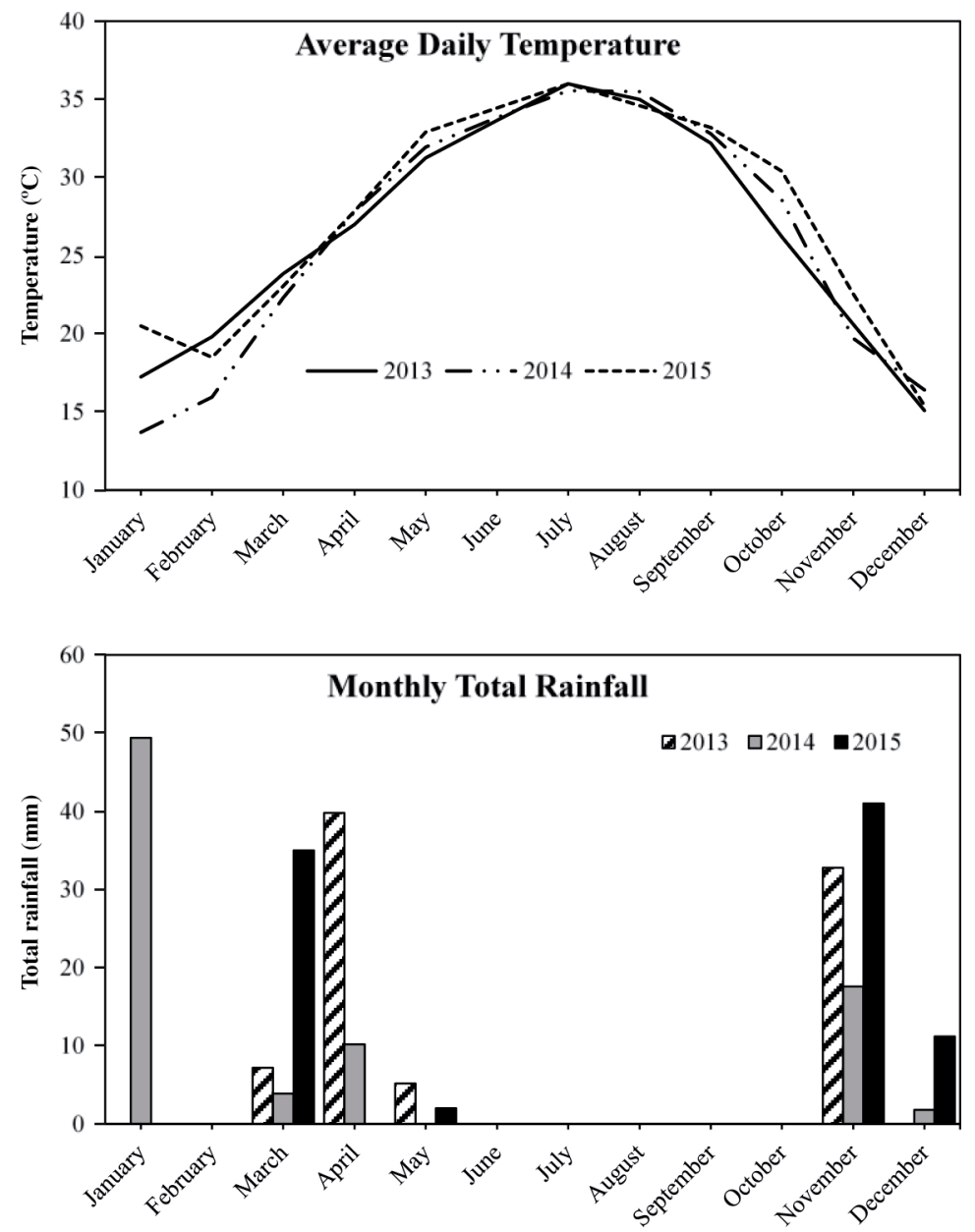

The total polyphenol content (TPC) was determined according to the method of Hayat (2020). In summary, $25 \mu \mathrm{L}$ extract were mixed with $1500 \mu \mathrm{L}$ water and then $125 \mu \mathrm{L}$ reagent (undiluted Folin Ciocalteau) was added to the mixture. After 1 min incubation, $375 \mu \mathrm{L} 20 \%$ sodium carbonate were added and the final volume of the mixture was made to 2500 $\mu \mathrm{L}$ by adding $475 \mu \mathrm{L}$ water. Spectrophotometer (Jenway 6705 UV/Vis., Cole-Parmer, Staffordshire, UK) was used to determine absorbance at $760 \mathrm{~nm}$ after $30 \mathrm{~min}$ incubation time at room temperature. Gallic acid (gallic acid equivalents, GAE) was used as standard to express TPC per gram dry weight of the sample (mg GAE g-1 DW).

\section{Total flavonoid content}

The total flavonoid content (TFC) was determined according to the method of Hayat (2020). Briefly, extract (250 $\mu \mathrm{L}$ ) was combined with $1000 \mu \mathrm{L}$ water and then $75 \mu \mathrm{L}$ each $\mathrm{NaNO}_{2}$ and $\mathrm{AlCl}_{3}$ were added. The mixture was incubated for $5 \mathrm{~min}$ at room temperature and then $500 \mu \mathrm{L} 1 \mathrm{M} \mathrm{NaOH}$ and $600 \mu \mathrm{L}$ water were added. Spectrophotometer was used to detect absorbance at $510 \mathrm{~nm}$. Blank was prepared without extract. Total flavonoids were expressed as the mean \pm standard deviation (SD) $\mathrm{mg}$ catechin equivalents (CE) $\mathrm{g}^{-1}$ alfalfa powder as determined by a calibration curve prepared with an external standard.

\section{DPPH scavenging}

The free radical scavenging capacity of the extract was determined using diphenylpicryl hydrazine (DPPH) using the method described by Noreen et al. (2017) with some modifications. An aliquot of extract (130 $\mu \mathrm{L})$ and $0.1 \mathrm{mM} \mathrm{DPPH}$ solution was mixed and incubated in the dark for $30 \mathrm{~min}$ and then absorbance was measured at $510 \mathrm{~nm}$. Control was 
prepared in the same manner, but ethanol was used instead of extract. Ethanol was used as a blank. The scavenging percentage was calculated by using the following equation:

\section{Reducing power}

$$
\text { DPPH scavenging } \%=\mathrm{A}_{\text {control }}-\mathrm{A}_{\text {sample }} / \mathrm{A}_{\text {control }} \times 100
$$

The ferric reducing power of the sample was determined according to the method of Hayat et al. (2010). In brief, $0.5 \mathrm{~mL}$ extract was mixed with $1.25 \mathrm{~mL}$ buffer $(0.2 \mathrm{M}, \mathrm{pH} 6.6)$ and $1.25 \mathrm{~mL}$ potassium ferricyanide, then incubated for $20 \mathrm{~min}$ at $50{ }^{\circ} \mathrm{C}$. After that, $1.25 \mathrm{~mL}$ trichloroacetic acid were added to the mixture and centrifuged at $3000 \times \mathrm{g}$ for $10 \mathrm{~min}$ at room temperature. An aliquot $(1.25 \mathrm{~mL}$ ) was taken from the supernatant, to which $1.25 \mathrm{~mL}$ water and $0.25 \mathrm{~mL}$ ferric chloride were added. The absorbance was measured at $700 \mathrm{~nm}$. Blank was prepared without extract.

\section{Statistical analysis}

Data obtained from each treatment (season) are reported as the average of $2 \mathrm{yr}$ and three replicates each year \pm SD. Means were compared using the least significant difference method, with a significance level of $\mathrm{P} \leq 0.05$. Pearson correlation coefficients were used to assess the relationships between different studied nutritive values of alfalfa leaves. All statistical tests were performed using SPSS Statistics 20.0 software (IBM, Armonk, New York, USA).

\section{RESULTS AND DISCUSSION}

\section{Fresh yield}

The fresh yield of alfalfa varied according to the seasons of the year, with the highest value in spring $\left(20 \mathrm{t} \mathrm{ha}^{-1}\right)$, followed by winter $\left(14.43 \mathrm{t} \mathrm{ha}^{-1}\right)$ and autumn $\left(13.58 \mathrm{t} \mathrm{ha}^{-1}\right)$, and then summer $\left(10.75 \mathrm{t} \mathrm{ha}^{-1}\right)$ (Table 1). The mild climate in terms of temperature in spring (Figure 1) led to this increase in fresh yield (Sharratt et al., 1986), whereas the rise in summer temperatures (Figure 1) led to a decrease in fresh yield (Sharratt et al., 1987; Bita and Gerats, 2013).

\section{Leaf:Stem ratio}

The ratio of leaves to stems was highest in spring (57.6\%), then autumn (56.7\%) and winter (56.1\%), and was lowest in summer (51.6\%) (Figure 2). This is due to the changes in weather during the seasons, which affects yield, quality, and ratio of leaves to stems and the growth of alfalfa plants (Brown and Tanner, 1983; Sanderson and Wedin, 1988).

\section{Nutritive value}

The correlations between different nutritive parameters of alfalfa leaves collected during different seasons were analyzed; Table 2 shows the Pearson's correlation coefficients between these parameters. Positive correlations were found between $\mathrm{DM}$ and crude ash (CA, $\mathrm{r}=0.853 ; \mathrm{P} \leq 0.01)$, DM and water-soluble carbohydrates (WSC, $\mathrm{r}=0.0 .717, \mathrm{P} \leq 0.01)$, ADF and digestibility (Dig, $r=0.726, P \leq 0.01)$, and neutral detergent fiber $(\mathrm{NDF})$ and $\operatorname{Dig}(\mathrm{r}=0.661, \mathrm{P} \leq 0.05)$. However, there were

Table 1. Changes in yield and nutritive value of alfalfa leaves collected during different seasons.

\begin{tabular}{|c|c|c|c|c|}
\hline Season & Winter & Spring & Summer & Autumn \\
\hline Yield, $\mathrm{t} \mathrm{ha}^{-1}$ & $13.87 \pm 0.10 b$ & $33.52 \pm 0.15 a$ & $13.95 \pm 0.12 b$ & $3.79 \pm 0.01 \mathrm{c}$ \\
\hline DM, \% & $27.45 \pm 0.44 a$ & $22.60 \pm 0.51 \mathrm{c}$ & $24.63 \pm 0.41 b$ & $21.38 \pm 0.54 \mathrm{c}$ \\
\hline $\mathrm{CA}, \%$ & $16.33 \pm 0.37 \mathrm{a}$ & $14.80 \pm 0.54 b$ & $14.67 \pm 0.26 b$ & $13.87 \pm 0.10 \mathrm{c}$ \\
\hline $\mathrm{CP}, \%$ & $31.98 \pm 0.04 c$ & $32.57 \pm 0.12 b$ & $32.93 \pm 0.10 b$ & $33.52 \pm 0.15 a$ \\
\hline $\mathrm{CF}, \%$ & $15.13 \pm 0.04 b$ & $15.18 \pm 0.05 b$ & $16.89 \pm 0.21 \mathrm{a}$ & $13.95 \pm 0.12 \mathrm{c}$ \\
\hline CFA, \% & $2.73 \pm 0.02 b$ & $2.32 \pm 0.03 c$ & $2.14 \pm 0.02 \mathrm{c}$ & $3.79 \pm 0.01 \mathrm{a}$ \\
\hline WSC, \% & $5.67 \pm 0.02 \mathrm{a}$ & $3.51 \pm 0.18 \mathrm{~d}$ & $5.14 \pm 0.04 b$ & $4.61 \pm 0.14 \mathrm{c}$ \\
\hline NDF, $\%$ & $26.11 \pm 0.17 \mathrm{c}$ & $29.53 \pm 0.18 \mathrm{a}$ & $23.54 \pm 0.19 d$ & $27.68 \pm 0.15 b$ \\
\hline $\mathrm{ADF}, \%$ & $18.38 \pm 0.11 b$ & $19.83 \pm 0.17 \mathrm{a}$ & $18.50 \pm 0.12 b$ & $16.55 \pm 0.08 c$ \\
\hline Dig, $\%$ & $87.32 \pm 0.12 \mathrm{a}$ & $87.95 \pm 0.05 a$ & $86.10 \pm 0.03 b$ & $86.20 \pm 0.27 b$ \\
\hline
\end{tabular}

Values are the average of $2 \mathrm{yr}$ (2013-2014 and 2014-2015), with three replicates each. Values are shown as means \pm standard deviation (SD). Means in the same row followed by the same letter are not significantly different $(\mathrm{P} \leq 0.05)$ according to Duncan's multiple range test.

DM: Dry matter; CA: crude ash; CP: crude protein; CF: crude fiber; CFA: crude fat; WSC: water-soluble carbohydrates; NDF: neutral detergent fiber; ADF: acidic detergent fiber; Dig: digestibility. 
multiple negative correlations. $\mathrm{DM}$ and crude protein $(\mathrm{CP}, \mathrm{r}=-0.798, \mathrm{P} \leq 0.01), \mathrm{CP}$ and $\mathrm{CA}(\mathrm{r}=-0.893, \mathrm{P} \leq 0.01)$, crude fat (CFA) and crude fiber (CF, $r=-0.860, \mathrm{P} \leq 0.01)$, NDF and WSC $(r=-0.771, \mathrm{P} \leq 0.01)$ and CFA and acid detergent fiber (ADF) $(\mathrm{r}=-0.863, \mathrm{P} \leq 0.01)$ were negatively correlated. Furthermore, there were negative correlations between $\mathrm{CF}$ and $\mathrm{NDF}(\mathrm{r}=-0.706, \mathrm{P} \leq 0.05), \mathrm{CP}$ and ADF $(\mathrm{r}=-0.625, \mathrm{P} \leq 0.05)$, and $\mathrm{CP}$ and $\mathrm{Dig}(\mathrm{r}=-0.659, \mathrm{P} \leq 0.05)$.

The data obtained in this study showed a significant difference in the amount of DM in alfalfa leaves in different seasons of the year (Table 1). DM reached its highest levels in winter (27.45\%) and its lowest levels in autumn (21.38\%). This may be mainly due to the climate conditions in Saudi Arabia, which is classified as an arid region, with higher rainfall percentages and lower temperatures during winter, which are favorable conditions for the growth of alfalfa plants. Similarly, there was significant difference between CA content in alfalfa leaves collected in winter, as compared to those collected in autumn (Table 1). However, CP content in alfalfa leaves was highest in autumn (Table 1) and lowest in winter (31.98\%). Overall, CP percentages in the different seasons were higher than those reported in other studies. Protein content in alfalfa leaves has previously been reported to be 28\% (Sommer and Sundrum, 2014). Milić et al. (2011) studied the chemical composition of different alfalfa cultivars and found that protein content ranged from $18.4 \%$ to $20.9 \%$ in all cultivars. They concluded that leaves of different cultivars accumulate more protein and minerals than stems. However, fiber content is lower in alfalfa leaves than in the stems. Furthermore, different alfalfa cultivars have been shown to have $\mathrm{CP}$ content ranging from $18.8 \%$ to $20.2 \%$ (Twidwell et al., 2002). In general, green leaves of alfalfa plants are considered to be a rich source of protein that has not yet been fully utilized (Firdaous et al., 2017).

Figure 2. Average leaf:stem ratio over 2 yr during all seasons, with three replicates each.

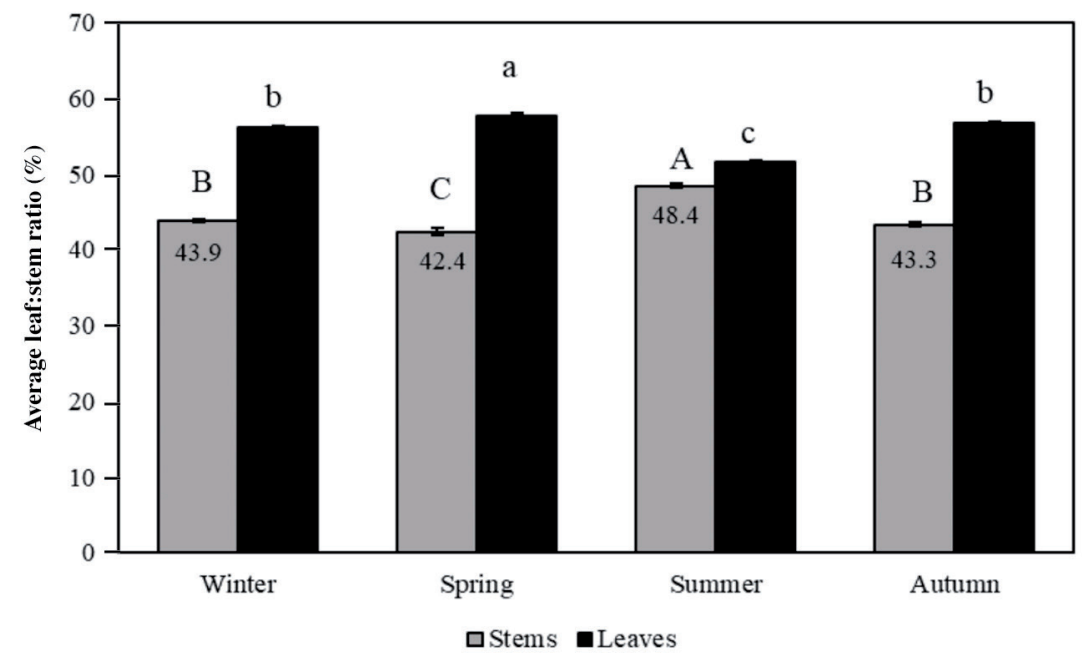

Different letters indicate significant differences in the percentage of leaves (lowercase letters) and stems (uppercase letters) between the seasons according to Duncan's multiple range test $(\mathrm{P} \leq 0.05)$.

Table 2. Pearson's correlation coefficients between different nutritive values of alfalfa leaves.

\begin{tabular}{lccccccccc}
\hline & DM & CA & CP & CF & CFA & WSC & NDF & ADF & Dig \\
\hline DM & 1 & & & & & & & & \\
CA & $0.853^{* *}$ & 1 & & & & & & & \\
CP & $-0.798^{* *}$ & $-0.893^{* *}$ & 1 & & & & & & \\
CF & 0.421 & 0.191 & -0.261 & 1 & & & & \\
CFA & -0.427 & -0.381 & 0.540 & $-0.860^{* *}$ & 1 & & & \\
WSC & $0.717^{* *}$ & 0.502 & -0.284 & 0.239 & 0.063 & 1 & & \\
NDF & -0.505 & -0.181 & 0.023 & $-0.706^{*}$ & 0.311 & $-0.771^{* *}$ & 1 & & \\
ADF & 0.265 & 0.365 & $-0.625^{*}$ & 0.508 & $-0.863^{* *}$ & -0.405 & 0.194 & 1 & \\
Dig & 0.177 & 0.472 & $-0.659^{*}$ & -0.168 & -0.345 & -0.454 & $0.661^{*}$ & $0.726^{* *}$ & 1
\end{tabular}

DM: Dry matter; CA: crude ash; CP: crude protein; CF: crude fiber; CFA: crude fat; WSC: water-soluble carbohydrates; NDF: neutral detergent fiber; ADF: acidic detergent fiber; Dig: digestibility. $\mathrm{N}=12 . * \mathrm{P} \leq 0.05 ; * * \mathrm{P} \leq 0.01$. 
In addition to $\mathrm{CP}$ content, ligneous cellulose content is one of the most important quality indicators of alfalfa leaves (Milić et al., 2011). Crude fiber content showed different values in the different seasons, except for winter and spring when the values did not differ significantly (Table 1). The highest crude fiber content was found in summer (16.89\%) and the lowest was found in autumn (13.95\%). Nevertheless, NDF content showed a high degree of variance between different seasons (Table 1). The highest NDF content was found in spring (29.53\%), while the lowest NDF content was found in summer (23.54\%). NDF content is a reliable indicator of the intake rate of alfalfa DM. Lower values of NDF content indicate higher quality, due to higher levels of nutrient uptake. However, ADF is a major indicator of potential production energy. Therefore, increased ADF content in alfalfa leaves indicates a potential decrease in energy and nutritive quality of the leaves (Katić et al., 2008). Our results showed that ADF content in alfalfa leaves reached the highest values in spring $(19.83 \%$, Table 1) and the lowest values in autumn (16.55\%). The results obtained in this study showed that alfalfa leaves had the lowest fiber content (crude fiber and ADF) and the highest CP content in autumn. High protein content and low fiber content are indicators of high nutritive quality (Milić et al., 2011). Moreover, our results showed that there was a negative correlation between CP and crude fiber content in alfalfa leaves (Table 2).

Analysis of CFA content in alfalfa leaves showed a high degree of variance between the different seasons (Table 1). The highest CFA content was found in samples collected in autumn, while the lowest CFA content was found in samples collected in summer (3.79\% and $2.14 \%$, respectively). Low CFA content indicates high nutritive quality of alfalfa leaves (Katić et al., 2008). On the contrary, WSC content in alfalfa leaves reached the highest values during winter (5.67\%) and decreased to the lowest values during spring (3.51\%). These data showed significant differences in WSC content of alfalfa leaves in different seasons (Table 1).

Digestibility is one of the most important indicators of good nutritive value. There were significant differences among digestibility values of alfalfa leaves collected during different seasons of the year (Table 1). The highest digestibility values were found in spring $(87.95 \%)$, whereas summer and autumn showed the lowest digestibility values, with nonsignificant differences between these two seasons. Sommer and Sundrum (2014) found that the digestibility of alfalfa leaves was $74 \%$. Alfalfa leaves from spring growth have been shown to have higher digestibility than leaves from summer regrowth (Tremblay et al., 2002). High digestibility values in spring may be attributed to the fresh growth of alfalfa plants during this season. Mature alfalfa plants are generally characterized by low digestibility because of an increase in the amount of cell wall material in the stems and leaves (Tremblay et al., 2002). Leaves grown in summer are often more mature, with more lignified cell walls compared to leaves grown in spring (Sanderson and Wedin, 1988). Lignin inhibits the digestibility of polysaccharides and thus, higher lignin content in cell walls decreases the digestibility and nutritive quality of alfalfa leaves (Katić et al., 2008). It has been shown that alfalfa leaves with high DM content and digestibility have more nutritive value for cows and humans (Émile et al., 1997).

\section{Effect of extraction solvents on the TPC and TFC of alfalfa}

The ethanol extract contains higher amount of TPC and TFC compared with distilled water extract (Figure 3). The higher TPC and TFC were observed in the ethanol extract (6.41 and $4.88 \mathrm{mg} \mathrm{GAE} \mathrm{g}^{-1} \mathrm{DW}$, respectively). It is argued that methanol has the highest efficiency for extraction of flavonoids and phenols; however, ethanol is the safest extractor with the lowest residues. Such increase in TPC and TFC amounts in ethanol extracts may be attributed to the solvent polarity. The highest amounts of flavonoids were obtained via extraction with 70\% ethanol in Mentha longifolia (Stanisavljević et al., 2012) and Eriobotrya japonica plants (Zhou et al., 2011). Many studies described that ethanol solvent can extract higher TPC and TFC of the plant samples compared with distilled water (Do et al., 2014). Our results agree with previous reports of total flavonoid contents in alfalfa leaves (Stochmal and Oleszek, 2007; Jing et al., 2015; Babakhani et al., 2017). Similarly, TPC contents revealed in our study are in accordance with the findings of previous reports (Babakhani et al., 2017; Chen et al., 2020).

\section{DPPH scavenging capacity and reducing power of alfalfa}

The effect of extraction solvents on DPPH scavenging capacity of alfalfa is shown in Figure 4a. In a similar way ethanol extract was significantly higher in DPPH scavenging capacity compared with water extraction. There was significant difference in DPPH scavenging capacity between ethanol extract (15.99\%) and distilled water extract (13.75\%). The ferric ion reducing power of ethanol and distilled water extraction of alfalfa is shown in Figure $4 \mathrm{~b}$. The reducing power of alfalfa 
Figure 3. Effect of extraction solvents on the total polyphenol (TPC) and total flavonoid (TFC) contents of alfalfa.

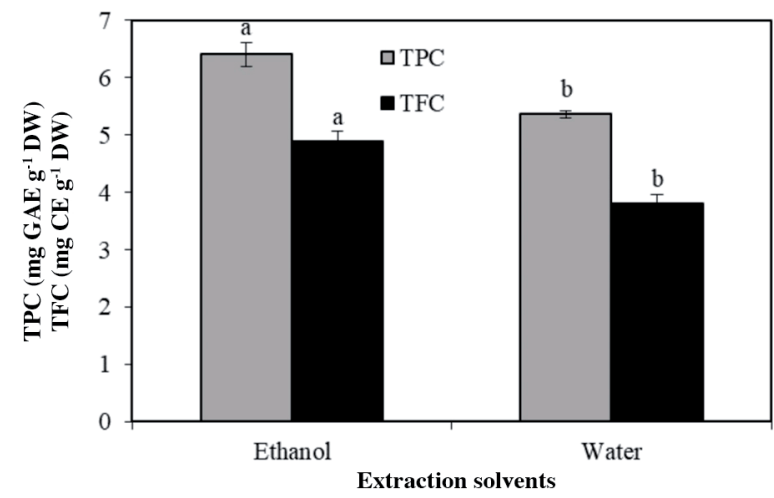

Different letters indicate significant differences in the contents of TPC and TFC between the seasons according to Duncan's multiple range test $(\mathrm{P} \leq 0.05)$.

GAE: Gallic acid equivalents; CE: catechin equivalents; DW: dry weight.

Figure 4. Effect of extraction solvents on the DPPH scavenging capacity (a) and reducing power of alfalfa (b).
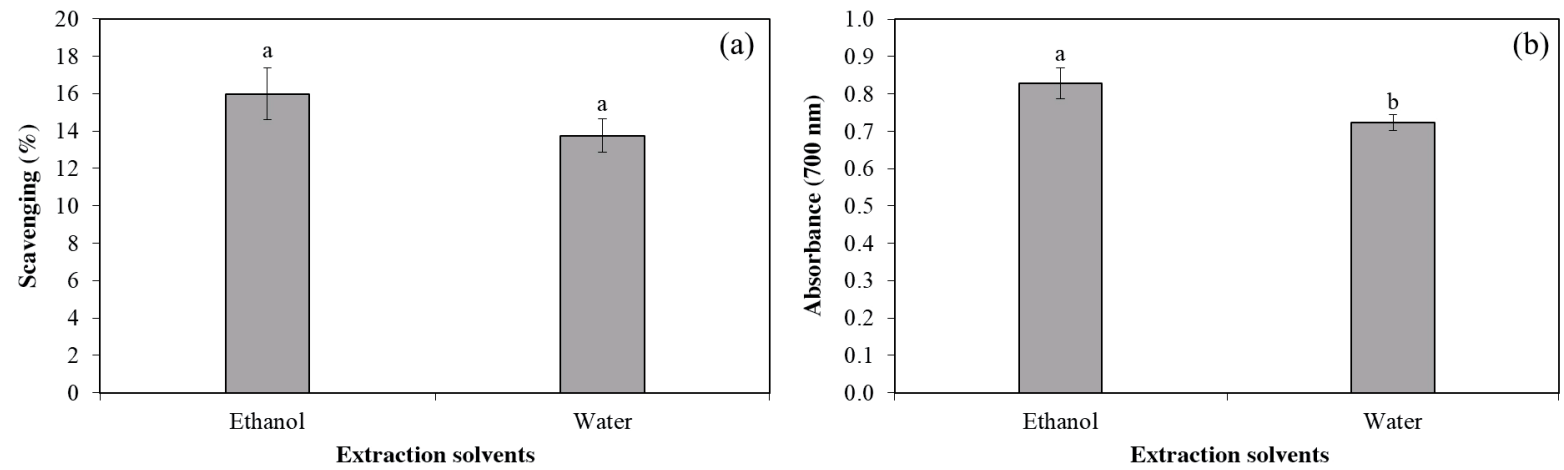

Different letters indicate significant according to Duncan's multiple range test $(\mathrm{P} \leq 0.05)$.

samples showed a similar trend as the DPPH scavenging. All the samples were tested at a concentration of $1 \mathrm{mg} \mathrm{mL}^{-1}$ and the ethanol extracted sample showed a non-significantly higher reducing power $(0.828)$ than the distilled water extracted sample (0.724). The results of reducing power and DPPH scavenging echoed the trend of TPC and TFC of alfalfa samples which showed that the antioxidant capacity of the samples was in a part due to their flavonoid and phenolic contents. Oxidative stress adversely affects health as a result of oxidation of lipids, proteins, and even DNA leading to cell and tissue damage in addition to other malfunctional effects and diseases (Battino et al., 2020; Corteselli et al., 2020). Flavonoids and phenols may stimulate the antioxidant activity alleviating such adverse effects of oxidative stress. Indeed, flavonoids act as antioxidant molecules via scavenging oxygen free radicals and inhibiting the superoxide ion formation and thus indirectly inhibiting prooxidant enzymes and redox-sensitive gens and transcription factors (Battino et al., 2020; Chen et al., 2020). On the other hand, the antioxidant activity of polyphenols is attributed mainly to activation of antioxidant enzymes via providing the required hydrogen atom from their hydroxyl groups (Ebrahimzadeh et al., 2018).

\section{CONCLUSIONS}

There were significant differences in all the studied parameters between cuts of alfalfa collected in different seasons (autumn, winter, spring, and summer). Fresh yield and leaf:stem ratio were highest in spring, followed by winter and autumn (with nonsignificant differences), and were lowest in summer. The autumn cut showed the highest crude protein and crude fat content, whereas leaves cut in autumn had the lowest crude fiber and acid detergent fiber content. The results obtained in this study suggested that autumn was the best season to cut alfalfa leaves for nutritional purposes in arid areas. 
However, alfalfa leaves cut in autumn were characterized by low digestibility values, which may affect their potential benefits. Further research is needed to confirm these results and identify the most suitable timing for cutting alfalfa leaves for nutritional purposes.

\section{ACKNOWLEDGEMENTS}

The authors extend their appreciation to the Deputyship for Research \& Innovation, Ministry of Education in Saudi Arabia for funding this research work through the project number IFKSURG-063.

\section{REFERENCES}

Al-Dosari, M.S. 2012. In vitro and in vivo antioxidant activity of alfalfa (Medicago sativa L.) on carbon tetrachloride intoxicated rats. The American Journal of Chinese Medicine 40(4):779-793. doi:10.1142/S0192415X12500589.

Al-Rimawi, F., Rishmawi, S., Ariqat, S.H., Khalid, M.F., Warad, I., and Salah, Z. 2016. Anticancer activity, antioxidant activity, and phenolic and flavonoids content of wild Tragopogon porrifolius plant extracts. Evidence-Based Complementary and Alternative Medicine 9612490. doi:10.1155/2016/9612490.

Babakhani, B., Hosseini Boldaji, S.A., and Sajedi, R.H. 2017. Biochemical and physiological responses of alfalfa (Medicago sativa L.) cultivars to osmotic stress. Journal of Plant Physiology \& Breeding 7(1):87-97.

Bákonyi, N., Kisvarga, S., Barna, D., Tóth, I.O., El-Ramady, H., Abdalla, et al. 2020. Chemical traits of fermented alfalfa brown juice: Its implications on physiological, biochemical, anatomical, and growth parameters of Celosia. Agronomy 10(2):247. doi:10.3390/agronomy10020247.

Battino, M., Giampieri, F., Cianciosi, D., Ansary, J., Chen, X., Zhang, D., et al. 2020. The roles of strawberry and honey phytochemicals on human health: A possible clue on the molecular mechanisms involved in the prevention of oxidative stress and inflammation. Phytomedicine 2020:153170. https://doi.org/10.1016/j.phymed.2020.153170.

Bita, C., and Gerats, T. 2013. Plant tolerance to high temperature in a changing environment: scientific fundamentals and production of heat stress-tolerant crops. Frontiers in Plant Science 4:273. doi:10.3389/fpls.2013.00273.

Bora, K.S., and Sharma, A. 2011. Phytochemical and pharmacological potential of Medicago sativa: A review. Pharmaceutical Biology 49(2):211-220. doi:10.3109/13880209.2010.504732.

Brown, P.W., and Tanner, C. 1983. Alfalfa stem and leaf growth during water stress. Agronomy Journal 75(5):799-805. doi:10.2134/agronj1983.00021962007500050017x.

Chen, S., Li, X., Liu, X., Wang, N., An, Q., Ye, X.M., et al. 2020. Investigation of chemical composition, antioxidant activity, and the effects of alfalfa flavonoids on growth performance. Oxidative Medicine and Cellular Longevity 2020:8569237. doi:10.1155/2020/8569237.

Corteselli, E.M., Gold, A., Surratt, J., Cui, T., Bromberg, P., Dailey, L., et al. 2020. Supplementation with omega-3 fatty acids potentiates oxidative stress in human airway epithelial cells exposed to ozone. Environmental Research 187109627. doi:10.1016/j.envres.2020.109627.

Do, Q.D., Angkawijaya, A.E., Tran-Nguyen, P.L., Huynh, L.H., Soetaredjo, F.E., Ismadji, S., et al. 2014. Effect of extraction solvent on total phenol content, total flavonoid content, and antioxidant activity of Limnophila aromatica. Journal of Food and Drug Analysis 22(3):296-302. doi:10.1016/j.jfda.2013.11.001.

Ebrahimzadeh, S., Navidshad, B., Farhoomand, P., and Aghjehgheshlagh, F.M. 2018. Effects of exogenous tannase enzyme on growth performance, antioxidant status, immune response, gut morphology and intestinal microflora of chicks fed grape pomace. South African Journal of Animal Science 48(1):2-18. doi:10.4314/sajas.v48i1.2.

Émile, J., Mauries, M., Allard, G., and Guy, P. 1997. Genetic variation in the feeding value of alfalfa genotypes evaluated from experiments with dairy cows. Agronomie 17(2):119-125. doi:10.1051/agro:19970205.

Eruygur, N., Dincel, B., Dincel, N.G.K., and Ucar, E. 2018. Comparative study of in vitro antioxidant, acetylcholinesterase and butyrylcholinesterase activity of alfalfa (Medicago sativa L.) collected during different growth stages. Open Chemistry 16(1):963-967. doi:10.1515/chem-2018-0088.

Firdaous, L., Fertin, B., Khelissa, O., Dhainaut, M., Nedjar, N., Chataigné, G., et al. 2017. Adsorptive removal of polyphenols from an alfalfa white proteins concentrate: Adsorbent screening, adsorption kinetics and equilibrium study. Separation and Purification Technology 178:29-39. doi:10.1016/j.seppur.2017.01.009.

Getachew, G., Laca, E.A., Putnam, D.H., Witte, D., McCaslin, M., Ortega, K.P., et al. 2018. The impact of lignin downregulation on alfalfa yield, chemical composition, and in vitro gas production. Journal of the Science of Food and Agriculture 98(11):4205-4215. doi:10.1002/jsfa.8942.

Hadidi, M., Ibarz, A., Conde, J., and Pagan, J. 2019. Optimisation of steam blanching on enzymatic activity, color and protein degradation of alfalfa (Medicago sativa) to improve some quality characteristics of its edible protein. Food Chemistry 276:591-598. doi:10.1016/j.foodchem.2018.10.049. 
Hayat, K. 2020. Impact of drying methods on the functional properties of peppermint (Mentha piperita L.) leaves. Science Letters 8(1):36-42.

Hayat, K., Zhang, X., Chen, H., Xia, S., Jia, C., and Zhong, F. 2010. Liberation and separation of phenolic compounds from citrus mandarin peels by microwave heating and its effect on antioxidant activity. Separation and Purification Technology 73(3):371-376. doi:10.1016/j.seppur.2010.04.026.

Jing, C.-L., Dong, X.-F., and Tong, J.-M. 2015. Optimization of ultrasonic-assisted extraction of flavonoid compounds and antioxidants from alfalfa using response surface method. Molecules 20(9):15550-15571. doi:10.3390/molecules200915550.

Katić, S., Mihailović, V., Milić, D., Karagić, Đ., Glamočić, D., and Jajić, I. 2008. Genetic and seasonal variations of fibre content in lucerne. Abstract 130. In Lübberstedt, T., Studer, B., and Graugaard, S. (eds.) Proceedings of The XXVII ${ }^{\text {th }}$ Eucarpia Symposium on Improvement of Fodder Crops and Amenity Grasses, Copenhagen. 19-23 August 2007. EUCARPIA, Wageningen, The Netherlands.

Milić, D., Karagić, Đ., Vasiljević, S., Mikić, A., Mijić, B., and Katić, S. 2011. Leaf and stem chemical composition of divergent alfalfa cultivars. Biotechnology in Animal Husbandry 27(4):1505-1511. doi:10.2298/bah1104505m.

Morin, C., Bélanger, G., Tremblay, G.F., Bertrand, A., Castonguay, Y., Drapeau, R., et al. 2011. Diurnal variations of nonstructural carbohydrates and nutritive value in alfalfa. Crop Science 51(3):1297-1306. doi:10.2135/cropsci2010.07.0406.

Noreen, H., Semmar, N., Farman, M., and McCullagh, J.S.O. 2017. Measurement of total phenolic content and antioxidant activity of aerial parts of medicinal plant Coronopus didymus. Asian Pacific Journal of Tropical Medicine 10(8):792-801. doi:10.1016/j.apjtm.2017.07.024.

Ouyang, K., Xu, M., Jiang, Y., and Wang, W. 2016. Effects of alfalfa flavonoids on broiler performance, meat quality, and gene expression. Canadian Journal of Animal Science 96(3):332-341. doi:10.1139/cjas-2015-0132.

Rahman, A.H.M.M. and Parvin, M.I.A. 2014. Study of medicinal uses on Fabaceae family at Rajshahi, Bangladesh. Research in Plant Sciences 2(1):6-8. doi:10.12691/plant-2-1-2.

Sadeghi, L., Tanwir, F., and Babadi, V.Y. 2016. Antioxidant effects of alfalfa can improve iron oxide nanoparticle damage: In vivo and in vitro studies. Regulatory Toxicology and Pharmacology 81:39-46. doi:10.1016/j.yrtph.2016.07.010.

Sanderson,M.A., and Wedin, W. 1988. Cell wall composition of alfalfa stems at similar morphological stages and chronological age during spring growth and summer regrowth. Crop Science 28(2):342-347. doi:10.2135/cropsci1988.0011183X002800020034x.

Sharratt, B., Baker, D., and Sheaffer, C. 1986. Climatic effect on alfalfa dry matter production. Part I. Spring harvest. Agricultural and Forest Meteorology 37(2):123-131. doi:10.1016/0168-1923(86)90003-1.

Sharratt, B., Baker, D., and Sheaffer, C. 1987. Climatic effect on alfalfa dry matter production. Part II. Summer harvests. Agricultural and Forest Meteorology 39(2-3):121-129. doi:10.1016/0168-1923(87)90031-1.

Silva, S., Gomes, L., Leitão, F., Coelho, A.V., and Boas, L.V. 2006. phenolic compounds and antioxidant activity of Olea europaea L. fruits and leaves. Food Science and Technology International 12(5):385-395. doi:10.1177/1082013206070166.

Silva, V.P., Pereira, O.G., Leandro, E.S., Da Silva, T.C., Ribeiro, K.G., Mantovani, H.C., et al. 2016. Effects of lactic acid bacteria with bacteriocinogenic potential on the fermentation profile and chemical composition of alfalfa silage in tropical conditions. Journal of Dairy Science 99(3):1895-1902. doi:10.3168/jds.2015-9792.

Sommer, H., and Sundrum, A. 2014. Determining the feeding value and digestibility of the leaf mass of alfalfa (Medicago sativa) and various types of clover. Proceedings of $11^{\text {th }}$ European IFSA Symposium, Farming Systems Facing Global Challenges: Capacities and Strategies, Berlin. 1-4 April 2014. International Farming Systems Association (IFSA) Europe Group, Vienna, Austria.

Stanisavljević, D.M., Stojicević, S.S., Dorđević, S.M., Zlatković, B.P., Velicković, D.T., Karabegović, I.T., et al. 2012. Antioxidant activity, the content of total phenols and flavonoids in the ethanol extracts of Mentha longifolia (L.) Hudson dried by the use of different techniques. Chemical Industry and Chemical Engineering Quarterly 18(3):411-420. doi:10.2298/CICEQ110919017S.

Stochmal, A., and Oleszek, W. 2007. Seasonal and structural changes of flavones in alfalfa (Medicago sativa) aerial parts. Journal of Food Agriculture and Environment 5(2):84-88.

Tremblay, G., Bélanger, G., McRae, K., and Michaud, R. 2002. Leaf and stem dry matter digestibility and ruminal undegradable proteins of alfalfa cultivars. Canadian Journal of Plant Science 82(2):383-393. doi:10.4141/P01-122.

Twidwell, E.K., Thiex, N.J., and Skogberg, J.L. 2002. Forage yield and quality of multileaflet alfalfa. SDSU Extension Extra Archive, South Dakota State University, Brookings, South Dakota, USA. Available at https://openprairie.sdstate.edu/ extension_extra/280 (accessed October 2020).

Zhou, C., Sun, C., Chen, K., and Li, X. 2011. Flavonoids, phenolics, and antioxidant capacity in the flower of Eriobotrya japonica Lindl. International Journal of Molecular Sciences 12(5):2935-2945. doi:10.3390/ijms12052935. 